\title{
Chryseobacterium palustre sp. nov. and Chryseobacterium humi sp. nov., isolated from industrially contaminated sediments
}

\author{
Correspondence \\ Paula M. L. Castro \\ plcastro@esb.ucp.pt
}

\author{
Carlos Pires, ${ }^{1,2}$ Maria F. Carvalho, ${ }^{1}$ Paolo De Marco, ${ }^{3,4}$ Naresh Magan $^{2}$ \\ and Paula M. L. Castro ${ }^{1}$
}
${ }^{1}$ Escola Superior de Biotecnologia, Universidade Católica Portuguesa, Rua Dr António Bernardino de Almeida, 4200-072 Porto, Portugal
${ }^{2}$ Cranfield Health, Cranfield University, Building 52A, Cranfield, Bedford MK43 OAL, UK
${ }^{3}$ IBMC - Instituto de Biologia Molecular e Celular, Universidade do Porto, Rua Campo Alegre, 823, 4150-180 Porto, Portugal
${ }^{4}$ CICS - Centro de Investigação em Ciências da Saúde, Institudo Superior de Ciências da Saúde - Norte, CESPU, 4585-116 Gandra PRD, Portugal

Two Gram-staining-negative bacterial strains, designated $3 \mathrm{~A} 10^{\top}$ and $\mathrm{ECP} 37^{\top}$, were isolated from sediment samples collected from an industrially contaminated site in northern Portugal. These two organisms were rod-shaped, non-motile, aerobic, catalase- and oxidase-positive and formed yellow colonies. The predominant fatty acids were iso- $C_{15: 0}$, anteiso- $C_{15: 0}$, iso- $C_{17: 1} \omega 9 c$ and iso- $\mathrm{C}_{17: 0} 3-\mathrm{OH}$. The $\mathrm{G}+\mathrm{C}$ content of the DNA of strains $3 A 10^{\top}$ and $\mathrm{ECP} 37^{\top}$ was 43 and $34 \mathrm{~mol} \%$, respectively. The major isoprenoid quinone of the two strains was MK-6. 16S rRNA gene sequence analysis revealed that strains $3 A 10^{\top}$ and $E C P 37^{\top}$ were members of the family Flavobacteriaceae and were related phylogenetically to the genus Chryseobacterium. Strain $3 A 10^{\top}$ showed $16 \mathrm{~S}$ rRNA gene sequence similarity values of 97.2 and $96.6 \%$ to the type strains of Chryseobacterium antarcticum and Chryseobacterium jeonii, respectively; strain ECP37 ${ }^{\top}$ showed $97.3 \%$ similarity to the type strain of Chryseobacterium marinum. DNA-DNA hybridization experiments revealed levels of genomic relatedness of $<70 \%$ between strains $3 \mathrm{~A} 10^{\top}$ and $\mathrm{ECP} 37^{\top}$ and between these two strains and the type strains of $\mathrm{C}$. marinum, $\mathrm{C}$. antarcticum and C. jeonii, justifying their classification as representing two novel species of the genus Chryseobacterium. The names proposed for these organisms are Chryseobacterium palustre sp. nov. (type strain $3 A 10^{\top}=\mathrm{LMG} 24685^{\top}=\mathrm{NBRC} 104928^{\top}$ ) and Chryseobacterium

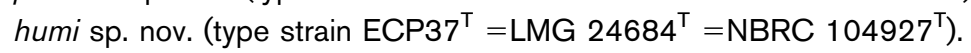

The genus Chryseobacterium was proposed by Vandamme et al. (1994). It belongs to the family Flavobacteriaceae and, at the time of writing, comprises 37 recognized species (Kämpfer et al., 2009). Chryseobacterium species may be found in soil and water environments and in clinical and dairy sources (Bernardet et al., 2006). Three flavobacteria previously classified as Sejongia antarctica, Sejongia jeonii (Yi et al., 2005) and Sejongia marina (Lee et al., 2007) have subsequently been transferred to the genus Chryseobacterium (Kämpfer et al., 2009).

Recently, the bacterial diversity of sediments collected from an industrially polluted site at Estarreja in northern Portugal was investigated. Sediments at the site have high

The GenBank/EMBL/DDBJ accession numbers for the 16S rRNA gene sequences of strains $3 A 10^{\top}$ and ECP37 $7^{\top}$ are EU360967 and EU360966, respectively. levels of contamination, especially by heavy metals (Costa \& Jesus-Rydin, 2001; Oliveira et al., 2001; Carvalho et al., 2002). Two different sampling occasions yielded two unidentified organisms that were related phylogenetically to the family Flavobacteriaceae (Bernardet et al., 2002). In the present study, a detailed classification of the two strains is provided on the basis of a polyphasic study, including analysis of morphological and physiological characteristics, cellular fatty acid profiling, DNA-DNA hybridization experiments and phylogenetic analysis of $16 \mathrm{~S}$ rRNA gene sequences. On the basis of the results obtained, strains $3 \mathrm{~A} 10^{\mathrm{T}}$ and $\mathrm{ECP} 37^{\mathrm{T}}$ are considered to represent two novel species of the genus Chryseobacterium.

Sediment samples were serially diluted in saline solution $(0.85 \%, w / v, \mathrm{NaCl})$ and were inoculated on trypticase soy

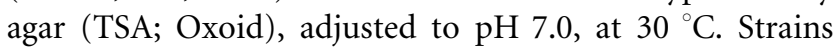


$3 \mathrm{~A} 10^{\mathrm{T}}$ and $\mathrm{ECP} 37^{\mathrm{T}}$, selected on the basis of colony morphology and colour, were purified by subculturing and were preserved at $-80{ }^{\circ} \mathrm{C}$ in modified Luria-Bertani broth (Tiago et al., 2004), supplemented with $15 \%$ (v/v) glycerol. Unless stated otherwise, all morphological and tolerance tests were performed by using TSA.

Cell morphology and gliding motility were examined by phase-contrast microscopy. Flagellar motility was tested as described by Alexander \& Strete (2001). Gram staining and catalase and cytochrome oxidase tests were performed as described by Murray et al. (1994) and Smibert \& Krieg (1994). Cell size was determined by using a Leica DM4000B light microscope equipped with Leica Applied Suite software. Presence of flexirubin pigments was investigated by using the bathochromatic test with a $20 \%$ $(\mathrm{w} / \mathrm{v}) \mathrm{KOH}$ solution as described by Bernardet et al. (2002).

Phenotypic tests listed below were performed on strains $3 \mathrm{~A} 10^{\mathrm{T}}$ and $\mathrm{ECP} 37^{\mathrm{T}}$ and on their closest phylogenetic neighbours, namely Chryseobacterium marinum NBRC $103143^{\mathrm{T}}$, Chryseobacterium antarcticum $\mathrm{AT}_{1013^{\mathrm{T}}}$ and Chryseobacterium jeonii $\mathrm{AT} 1047^{\mathrm{T}}$. The $\mathrm{pH}$ range for growth was determined in buffered trypticase soy broth (TSB) adjusted to $\mathrm{pH} 3-10$ (at $1 \mathrm{pH}$ unit intervals). Turbidity of the cultures grown in an orbital shaker at $25{ }^{\circ} \mathrm{C}$ was measured at $610 \mathrm{~nm}$. All buffer solutions used to adjust the $\mathrm{pH}$ of TSB were prepared from $1 \mathrm{M}$ stock solutions according to Gomori (1990). Citrate buffer was used for $\mathrm{pH} 3-6$, phosphate buffer for $\mathrm{pH} 7$, Tris buffer for $\mathrm{pH} 8$, and a carbonate-bicarbonate buffer for $\mathrm{pH} 9$ and 10 . Growth temperature ranges were determined on TSA incubated at $4,10,15,20,25,30,37$ and $50{ }^{\circ} \mathrm{C}$.

Growth in the presence of $0-20 \%(\mathrm{w} / \mathrm{v}) \mathrm{NaCl}$ (at $1 \%$ intervals up to $10 \%$, then at 12,15 and $20 \%$ ) was examined in TSB adjusted to $\mathrm{pH} 7$ and incubated at $25{ }^{\circ} \mathrm{C}$. The ability to grow under anaerobic conditions was evaluated by incubating TSA plates in an anaerobic jar (with $9-13 \% \mathrm{CO}_{2}$ ) in an oxygen-deprived atmosphere by using AnaeroGen (Oxoid) at $25{ }^{\circ} \mathrm{C}$ for 7 days.

Acid production from carbohydrates was examined in API $50 \mathrm{CH}$ test strips by using API $50 \mathrm{CHB} / \mathrm{E}$ medium (bioMérieux) according to the manufacturer's instructions. Single carbon source assimilation was also determined in API $50 \mathrm{CH}$ test strips (bioMérieux) by using cells suspended in $0.1 \mathrm{M}$ phosphate buffer $(\mathrm{pH} 7)$ supplemented with $0.7 \%$ yeast nitrogen base (Difco) and $0.05 \%$ $\mathrm{NH}_{4} \mathrm{Cl}$ (Tiago et al., 2005, 2006). Bacterial cells were suspended in sterilized water to reach a turbidity corresponding to McFarland No. 6 standard. Cell suspensions $(3 \mathrm{ml}$ ) were then added to $60 \mathrm{ml}$ medium and inoculated in the API $50 \mathrm{CH}$ test strip wells, according to the manufacturer's recommendations (bioMérieux). Nitrate reduction, indole production and the presence of $\beta$-galactosidase, $\mathrm{L}$-arginine dihydrolase and urease activities were determined by using API 20 NE strips and API AUX medium (bioMérieux). All the above results were recorded after $24,48,72$ and $120 \mathrm{~h}$ incubation at $25{ }^{\circ} \mathrm{C}$. Hydrolysis of arbutin, gelatin, casein, Tweens 20 and 80 and starch was tested on TSA as described by Hudson et al. (1986) and Smibert \& Krieg (1994). Antibiotic susceptibility was examined on TSA at $25{ }^{\circ} \mathrm{C}$ for $72 \mathrm{~h}$ with Oxoid discs (see species descriptions for details) following the interpretation criteria proposed by the Comite de l'Antibiogramme de la Société Française de Microbiologie (1998). The phenotypic characteristics of strains $3 \mathrm{~A}_{10}^{\mathrm{T}}$ and $\mathrm{ECP} 37^{\mathrm{T}}$ are given in Table 1 and in the species descriptions.

Genomic DNA for determination of the $\mathrm{G}+\mathrm{C}$ content was obtained as described by Cashion et al. (1977). G + C ratios were estimated by the Identification Service of the Deutsche Sammlung von Mikroorganismen und Zellkulturen (DSMZ; Braunschweig, Germany) by HPLC as described by Mesbah et al. (1989). Fatty acid methyl esters were obtained from fresh wet biomass, grown on TSA at $28{ }^{\circ} \mathrm{C}$ for $24 \mathrm{~h}$, by saponification, methylation and extraction as described by Kuykendall et al. (1988), and the fatty acids were separated, identified and quantified according to the protocol of the Microbial Identification System, Sherlock version 4.6 (MIS-MIDI). The closest phylogenetic neighbours of strains $3 \mathrm{~A} 10^{\mathrm{T}}$ and $\mathrm{ECP} 37^{\mathrm{T}}$ were not included in the fatty acid analysis because they could not be grown under the same conditions as the new isolates. Analysis of respiratory quinones was also carried out at the DSMZ.

The major respiratory lipoquinone of strains $3 \mathrm{~A} 10^{\mathrm{T}}$ and ECP $37^{\mathrm{T}}$ was menaquinone 6 (MK-6), which is in accordance with all recognized members of the family Flavobacteriaceae (Bernardet et al., 2006). The fatty acid profile of strains $3 \mathrm{~A} 10^{\mathrm{T}}$ and $\mathrm{ECP} 37^{\mathrm{T}}$, like those of recognized species of the genus Chryseobacterium, was dominated by branched components, namely iso- $\mathrm{C}_{15: 0}$, iso- $\mathrm{C}_{17: 1} \omega 9 c$, anteiso- $\mathrm{C}_{15: 0}$ and iso- $\mathrm{C}_{17: 0} 3-\mathrm{OH}$. The detailed fatty acid profiles of strains $3 \mathrm{~A} 10^{\mathrm{T}}$ and $\mathrm{ECP} 37^{\mathrm{T}}$ are compared with those reported in the literature for related Chryseobacterium species (Yi et al., 2005; Lee et al., 2007) in Table 2. The $\mathrm{G}+\mathrm{C}$ content of the DNA of strains $3 \mathrm{~A} 10^{\mathrm{T}}$ and $\mathrm{ECP} 37^{\mathrm{T}}$ was 43 and $34 \mathrm{~mol} \%$, respectively. The DNA G $+C$ content of strain ECP $37^{\mathrm{T}}$ is in line with those reported for recognized Chryseobacterium species (Yi et al., 2005; Bernardet et al., 2006; Lee et al., 2007), but that of strain $3 \mathrm{~A} 10^{\mathrm{T}}$ is significantly higher (Bernardet et al., 2006), being similar to that of Kaistella koreensis (Kim et al., 2004).

Extraction of genomic DNA, PCR amplification of the $16 \mathrm{~S}$ rRNA gene and sequencing of the purified PCR products were carried out as described by Rainey et al. (1996). Cloning of the amplicons into pGEM T-Easy vector (Promega) and cycle sequencing were performed at Macrogen Inc. (Seoul, Republic of Korea) by using universal bacterial 16S rRNA primers (f27, f357, f519, f1114, r519, r800, r1056, r1492) (Lane, 1991). For phylogenetic analyses, the sequences were aligned by using the BioEdit program (version 7.0.5.3) (Hall, 1999) and 
Table 1. Differential characteristics between strains $3 A 10^{\top}$ and $E C P 37^{\top}$ and related species of the genus Chryseobacterium

Strains: $1,3 \mathrm{~A} 10^{\mathrm{T}}$; 2, ECP37 ${ }^{\mathrm{T}}$; 3, C. marinum NBRC $103143^{\mathrm{T}}$; 4, C. antarcticum AT1013 ${ }^{\mathrm{T}}$; 5, C. jeonii AT1047 ${ }^{\mathrm{T}}$. All data are from the present study. + , Positive; -, negative; $\mathrm{W}$, weakly positive. Data in parentheses were reported in the original descriptions of the species.

\begin{tabular}{|c|c|c|c|c|c|}
\hline Characteristic & 1 & 2 & 3 & 4 & 5 \\
\hline Colony pigmentation on TSA & Yellow & Yellow & Yellow & Pale yellow & Yellow \\
\hline Cell length $(\mu \mathrm{m})$ & $1.5-2.1$ & $1.6-2.5$ & $0.6-1.4$ & $1.3-3.1$ & $1.0-2.9$ \\
\hline Cell width $(\mu \mathrm{m})$ & 0.6 & $0.5-0.6$ & $0.5-0.7$ & $0.4-0.6$ & $0.4-0.5$ \\
\hline Catalase & + & w & + & + & + \\
\hline Oxidase & + & + & - & + & + \\
\hline \multicolumn{6}{|l|}{ Growth temperature $\left({ }^{\circ} \mathrm{C}\right)$} \\
\hline Range & $10-37$ & $4-37$ & $5-25$ & $5-25$ & $5-25$ \\
\hline Optimum & 30 & $25-30$ & 15 & 20 & 20 \\
\hline \multicolumn{6}{|l|}{$\mathrm{pH}$ for growth } \\
\hline Range & $6-9$ & $6-9$ & $7-9$ & $6-10$ & $6-10$ \\
\hline Optimum & 7 & $7-8$ & 7 & $7-8$ & $7-8$ \\
\hline \multicolumn{6}{|l|}{ Growth with $\mathrm{NaCl}(\%, \mathrm{w} / \mathrm{v})$} \\
\hline Range & $0-6$ & $0-7$ & $0-3$ & $0-3$ & $0-2$ \\
\hline Optimum & $2-3$ & 2 & $0-1$ & 1 & 0 \\
\hline Indole production & - & - & - & + & $-(+)$ \\
\hline \multicolumn{6}{|l|}{ Hydrolysis of: } \\
\hline Casein & + & + & - & $-(+)$ & $\mathrm{w}$ \\
\hline Starch & + & + & + & W & + \\
\hline Gelatin & + & + & + & $-(+)$ & $-(+)$ \\
\hline Arbutin & + & + & - & - & - \\
\hline Tween 20 & - & - & + & - & + \\
\hline Tween 80 & - & - & $-(+)$ & $-(+)$ & + \\
\hline \multicolumn{6}{|l|}{ Acid production from: } \\
\hline Galactose & $\mathrm{w}$ & - & + & $+(-)$ & - \\
\hline Lactose & - & $\mathrm{w}$ & - & - & - \\
\hline Gluconate & - & - & + & - & - \\
\hline L-Arabitol & - & - & + & - & - \\
\hline Cellobiose & - & + & - & - & - \\
\hline D-Mannose & $\mathrm{W}$ & - & - & - & $-(+)$ \\
\hline Starch & $\mathrm{w}$ & + & + & + & + \\
\hline Glycogen & - & + & - & + & + \\
\hline Amygdalin & - & + & - & - & - \\
\hline Arbutin & - & $\mathrm{w}$ & - & - & - \\
\hline Salicin & - & $\mathrm{w}$ & - & - & - \\
\hline 5-Ketogluconate & - & - & + & - & - \\
\hline Xylitol & - & $\mathrm{w}$ & - & - & - \\
\hline Gentiobiose & - & + & - & - & - \\
\hline DNA G $+C$ content $(\mathrm{mol} \%)$ & 43 & 34 & 35 & 34 & 36 \\
\hline
\end{tabular}

were analysed via the DNAML, SEQBOOT, DNAPARS, DNADIST (Kimura's two-parameter correction), NEIGHBOR, FITCH and CONSENSE programs of the PHYLIP package (Felsenstein, 1995). 16S rRNA gene sequences of other members of the family Flavobacteriaceae were obtained from the NCBI database (Benson et al., 2007). A manually corrected and degapped alignment of 31 sequences of $1249 \mathrm{nt}$ was used. The robustness of the phylogenetic tree was confirmed by using bootstrap analysis based on 100 resamplings of the sequences (1000 for the neighbour-joining analysis). Nonhomologous and ambiguous nucleotide positions were excluded from the calculations. In the neighbour-joining phylogenetic tree (Fig. 1), strains $3 \mathrm{~A} 10^{\mathrm{T}}$ and $\mathrm{ECP} 37^{\mathrm{T}}$ formed a monophyletic group with $C$. antarcticum $\mathrm{AT}_{1013^{\mathrm{T}}}$, C. jeonii AT1047 ${ }^{\mathrm{T}}$ and C. marinum NBRC $103143^{\mathrm{T}}$ supported by high bootstrap values $(82-99 \%)$. The other phylogenetic trees showed essentially the same topology (not shown). These results show that the two novel strains belong to the genus Chryseobacterium. Strain $3 \mathrm{~A} 10^{\mathrm{T}}$ showed $16 \mathrm{~S}$ rRNA gene sequence similarities of 97.2 and $96.6 \%$ to the type strains of C. antarcticum and $C$. jeonii, respectively, while strain $\mathrm{ECP} 37^{\mathrm{T}}$ showed $97.3 \%$ similarity to the type strain of $C$. marinum.

For DNA-DNA hybridization experiments, the genomic DNA of strains $3 \mathrm{~A} 10^{\mathrm{T}}$ and $\mathrm{ECP} 37^{\mathrm{T}}$ was hybridized and 
Table 2. Fatty acid contents of strains $3 A 10^{\top}$ and $E C P 37^{\top}$ and the type strains of related Chryseobacterium species

Strains: $1,3 \mathrm{~A} 10^{\mathrm{T}} ; 2, \mathrm{ECP} 37^{\mathrm{T}} ; 3$, C. marinum NBRC $103143^{\mathrm{T}}$ (data from Lee et al., 2007); 4, C. antarcticum $\mathrm{AT} 1013^{\mathrm{T}}$ (Yi et al., 2005); 5, C. jeonii $\mathrm{AT}_{1047^{\mathrm{T}}}$ (Yi et al., 2005). Not all strains were cultivated under the same conditions. Values are percentages of the total fatty acids. Cellular fatty acids that amount to $<1 \%$ of the total fatty acid content in all strains are not shown. -, Not detected; tr, trace $(<0.5 \%)$.

\begin{tabular}{|c|c|c|c|c|c|}
\hline Fatty acid & 1 & 2 & 3 & 4 & 5 \\
\hline iso $-\mathrm{C}_{12: 0}$ & - & - & - & 0.5 & 1.0 \\
\hline iso- $\mathrm{C}_{13: 0}$ & 3.1 & 5.8 & 0.6 & 2.5 & 2.9 \\
\hline anteiso- $\mathrm{C}_{13: 0}$ & $\operatorname{tr}$ & $\operatorname{tr}$ & $\operatorname{tr}$ & $\operatorname{tr}$ & $\operatorname{tr}$ \\
\hline iso- $\mathrm{C}_{14: 0}$ & 0.9 & 0.7 & 0.8 & 1.5 & 5.0 \\
\hline $\mathrm{C}_{15: 0}$ & - & - & - & 2.6 & 1.5 \\
\hline $\mathrm{C}_{15: 0} 2-\mathrm{OH}$ & 0.8 & 1.0 & 2.9 & 1.9 & 1.9 \\
\hline iso- $\mathrm{C}_{15: 0}$ & 40.0 & 45.0 & 17.0 & 13.6 & 12.2 \\
\hline iso- $\mathrm{C}_{15: 0} 3-\mathrm{OH}$ & 2.0 & 6.4 & 3.2 & 1.0 & 1.3 \\
\hline anteiso- $\mathrm{C}_{15: 0}$ & 17.0 & 8.0 & 33.8 & 15.2 & 24.2 \\
\hline anteiso- $\mathrm{C}_{15: 1}$ & - & - & - & 6.6 & - \\
\hline iso- $\mathrm{C}_{16: 0}$ & $\operatorname{tr}$ & $\operatorname{tr}$ & 0.6 & 2.8 & 5.7 \\
\hline iso- $\mathrm{C}_{16: 0} 3-\mathrm{OH}$ & 1.4 & 1.0 & 2.9 & 5.1 & 9.0 \\
\hline iso- $\mathrm{C}_{16: 1} \mathrm{H}$ & $\operatorname{tr}$ & - & 2.3 & 3.6 & 9.1 \\
\hline $\mathrm{C}_{16: 1} \omega 5 c$ & $\operatorname{tr}$ & $\operatorname{tr}$ & - & - & - \\
\hline $\mathrm{C}_{17: 0} 2-\mathrm{OH}$ & 0.8 & 0.5 & 5.9 & 3.3 & 2.3 \\
\hline iso- $\mathrm{C}_{17: 0} 3-\mathrm{OH}$ & 6.0 & 10.8 & 5.0 & 5.6 & 4.4 \\
\hline iso- $\mathrm{C}_{17: 1} \omega 9 c$ & 18.7 & 8.7 & 8.8 & 21.3 & 8.9 \\
\hline anteiso- $\mathrm{C}_{17: 1} \omega 9 c$ & $\operatorname{tr}$ & - & 2.3 & 2.5 & 1.9 \\
\hline $\mathrm{C}_{18: 1} \omega 5 c$ & 1.5 & 1.1 & 1.5 & 1.5 & 0.8 \\
\hline Unknown $11.543^{*}$ & $\operatorname{tr}$ & $\operatorname{tr}$ & - & - & - \\
\hline Unknown $13.565^{\star}$ & 0.7 & 1.4 & - & 0.7 & 0.4 \\
\hline Unknown $16.582^{*}$ & 0.7 & 1.0 & - & 0.5 & $\operatorname{tr}$ \\
\hline Summed feature $3 \dagger$ & 3.8 & 6.8 & - & - & - \\
\hline Summed feature $4 \dagger$ & 0.5 & 0.6 & - & 2.7 & 2.6 \\
\hline
\end{tabular}

${ }^{*}$ Unknown fatty acid; numbers indicate equivalent chain-length. $\dagger$ Summed features are groups of two or three fatty acids that cannot be reliably separated by GLC with the MIDI system. Summed feature 3 comprised iso- $\mathrm{C}_{15: 0} 2-\mathrm{OH}$ and/or $\mathrm{C}_{16: 1} \omega 7 c$; summed feature 4 comprised iso- $\mathrm{C}_{17: 1} \mathrm{I}$ and/or anteiso- $\mathrm{C}_{17: 1} \mathrm{~B}$.

each was hybridized with the DNA of the type strains of their closest phylogenetic neighbours, namely $C$. antarcticum AT1013 ${ }^{\mathrm{T}}$, C. jeonii AT1047 ${ }^{\mathrm{T}}$ and C. marinum NBRC $103143^{\mathrm{T}}$. DNA-DNA hybridization was performed at the DSMZ, as described by De Ley et al. (1970) with the modifications described by Huß et al. (1983), by using a model Cary 100 Bio UV/visual spectrometer equipped with a Peltier-thermostatted $6 \times 6$ multicell changer and a temperature controller with in-situ temperature probe (Varian). DNA was isolated by using a French pressure cell (Thermo Spectronic) and was purified by chromatography on hydroxyapatite as described by Cashion et al. (1977).

DNA-DNA hybridization experiments revealed levels of genomic relatedness of $15.2,29.5$ and $21.8 \%$ between strain $3 \mathrm{~A} 10^{\mathrm{T}}$ and C. marinum NBRC $103143^{\mathrm{T}}, \quad$ C. antarcticum $\mathrm{AT} 1013^{\mathrm{T}}$ and C. jeonii $\mathrm{AT} 1047^{\mathrm{T}}$, respectively. Levels of DNA-DNA relatedness between strain ECP $37^{\mathrm{T}}$ and C. marinum NBRC $103143^{\mathrm{T}}$, C. antarcticum AT1013 ${ }^{\mathrm{T}}$ and C. jeonii $\mathrm{AT}_{1047^{\mathrm{T}}}$ were $10.1,11.0$ and $7.4 \%$, respectively. DNA-DNA relatedness between strains $3 \mathrm{~A} 10^{\mathrm{T}}$ and $\mathrm{ECP} 37^{\mathrm{T}}$ was $19.8 \%$.

The data presented herein demonstrate that strains $3 \mathrm{~A} 10^{\mathrm{T}}$ and $\mathrm{ECP} 37^{\mathrm{T}}$ represent two novel species of the genus Chryseobacterium, for which the names Chryseobacterium palustre sp. nov. and Chryseobacterium humi sp. nov., respectively, are proposed. The new isolates can be differentiated from closely related species based on a combination of phenotypic features (Tables 1 and 2).

\section{Description of Chryseobacterium palustre sp. nov.}

Chryseobacterium palustre (pa.lus'tre. L. neut. adj. palustre pertaining to a marsh).

Cells are Gram-staining-negative, aerobic, chemoheterotrophic rods (1.5-2.1 $\mu \mathrm{m}$ long and $0.6 \mu \mathrm{m}$ in diameter). No flagellar or gliding motility. Colonies grown on TSA for 3 days are $0.3-1.2 \mathrm{~mm}$ in diameter, circular with regular edges and yellow. Flexirubin-type pigments are absent. Oxidase- and catalase-positive. Growth occurs at $10-37^{\circ} \mathrm{C}$ (optimum, about $30{ }^{\circ} \mathrm{C}$ ), at $\mathrm{pH}$ 6.0-9.0 (optimum, $\mathrm{pH}$ 7) and in the presence of $0-6.0 \% \mathrm{NaCl}$ (optimum, 2-3\%). Nitrite and nitrate are not reduced. Casein, gelatin, arbutin, aesculin and starch are hydrolysed. Positive for the VogesProskauer reaction (API 20NE). Urease and $\beta$-galactosidase activities are absent. Assimilates D-glucose, L-arabinose, Dmannose, $N$-acetylglucosamine, maltose, adipic acid, malic acid, trisodium citrate, L-xylose, D-fructose, L-sorbose, Lrhamnose, inositol, D-mannitol, D-sorbitol, lactose, sucrose, glycogen, potassium gluconate, potassium 2-ketogluconate and potassium 5-ketogluconate. Acid is produced from galactose, D-glucose, D-mannose, maltose and starch. Assimilation or acid production is negative for the other carbon sources in the API 50CH and API 20NE strips. The type strain is resistant to discs containing penicillin $G$ $(10 \mu \mathrm{g})$, polymyxin B $(300 \mu \mathrm{g})$, gentamicin $(10 \mu \mathrm{g})$, sulfamethoxazole $(25 \mu \mathrm{g})$, colistin sulfate $(50 \mu \mathrm{g})$ and meticillin $(5 \mu \mathrm{g})$, but susceptible to erythromycin $(15 \mu \mathrm{g})$, ceftazidime $(30 \mu \mathrm{g})$, cephalothin $(30 \mu \mathrm{g})$, tetracycline $(30 \mu \mathrm{g})$, amoxicillin $(25 \mu \mathrm{g})$, ciprofloxacin $(5 \mu \mathrm{g})$, ticarcillin $(75 \mu \mathrm{g})$, sulfamethoxazole/trimethoprim (1.25/ $23.75 \mu \mathrm{g})$, vancomycin $(30 \mu \mathrm{g})$, meropenem $(10 \mu \mathrm{g})$, streptomycin $(10 \mu \mathrm{g})$, lincomycin $(2 \mu \mathrm{g})$, rifampicin $(30 \mu \mathrm{g})$, cefoxitin $(30 \mu \mathrm{g})$, cephalothin $(30 \mu \mathrm{g})$, amoxicillin/clavulanic acid $(20 / 10 \mu \mathrm{g})$, chloramphenicol $(30 \mu \mathrm{g})$ and ampicillin $(10 \mu \mathrm{g})$. The major respiratory lipoquinone is MK-6. The major cellular fatty acids ( $\geqslant 6 \%$ of the total) are iso- $\mathrm{C}_{15: 0}$, anteiso- $\mathrm{C}_{15: 0}$, iso- $\mathrm{C}_{17: 1} \omega 9 c$ and iso- $\mathrm{C}_{17: 0} 3-$ $\mathrm{OH}$. Other cellular fatty acids are listed in Table 2 . The $\mathrm{G}+\mathrm{C}$ content of the genomic DNA of the type strain is $43 \mathrm{~mol} \%$. 


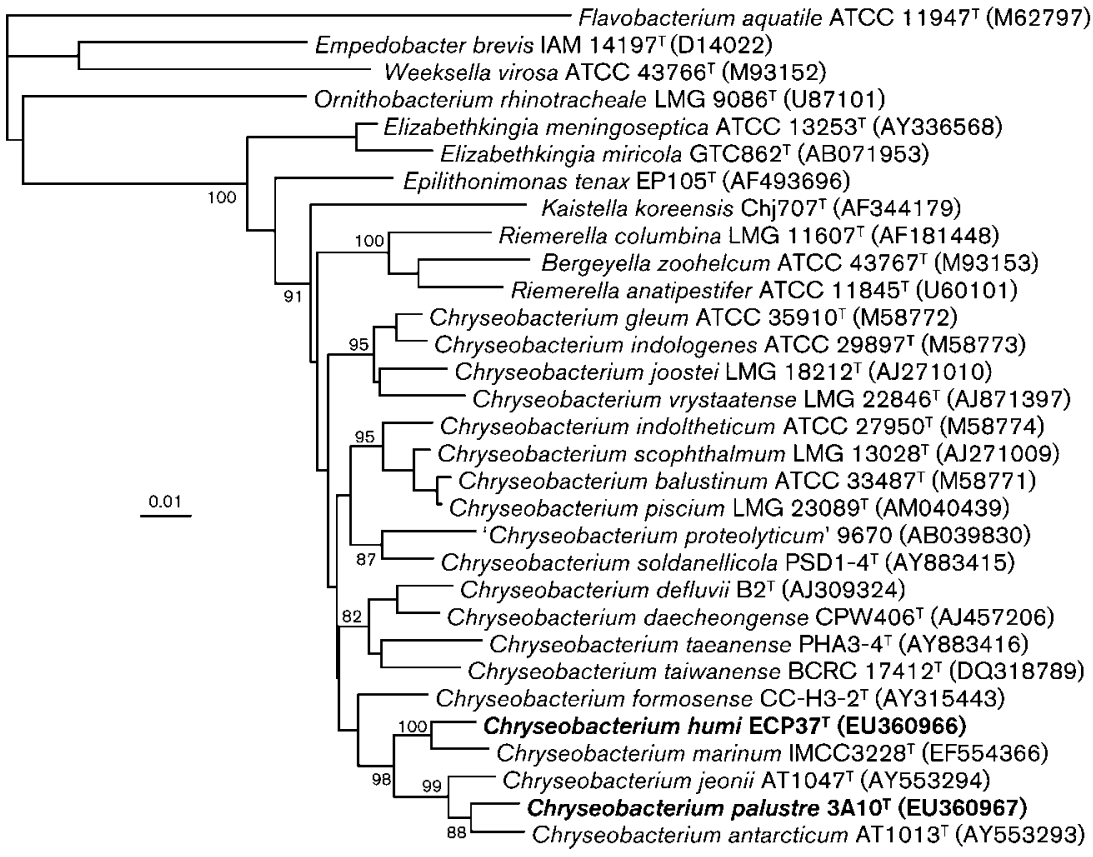

Fig. 1. Neighbour-joining phylogenetic tree, based on 16S rRNA gene sequences, showing the relationships between strains $3 A 10^{\top}$ and ECP37 ${ }^{\top}$ and representative members of the family Flavobacteriaceae. Bootstrap values $>80 \%$ are shown at nodes. The sequence of Flavobacterium aquatile ATCC $11947^{\top}$ was used as an outgroup. Bar, 0.01 substitutions per nucleotide position.
The type strain, $3 \mathrm{~A} 10^{\mathrm{T}}\left(=\mathrm{LMG} 24685^{\mathrm{T}}=\mathrm{NBRC} 104928^{\mathrm{T}}\right)$, was isolated from a rhizosphere sediment sample collected near a stream at a polluted site located in the industrial complex of Estarreja, northern Portugal.

\section{Description of Chryseobacterium humi sp. nov.}

Chryseobacterium humi (hu'mi. L. gen. n. humi of earth, soil).

Cells are Gram-staining-negative, aerobic, chemoheterotrophic rods $(1.6-2.5 \mu \mathrm{m}$ long and $0.5-0.6 \mu \mathrm{m}$ in diameter). No flagellar or gliding motility. Colonies grown on TSA for 3 days are $0.2-1.4 \mathrm{~mm}$ in diameter, circular with regular edges and yellow. Flexirubin-type pigments are absent. Oxidase- and catalase-positive. Growth occurs at 4$37{ }^{\circ} \mathrm{C}$ (optimum, 25-30 ${ }^{\circ} \mathrm{C}$ ), at $\mathrm{pH}$ 6.0-9.0 (optimum, $\mathrm{pH} 7.0-8.0)$ and in the presence of $0-7.0 \% \mathrm{NaCl}$ (optimum, 2\%). Nitrite and nitrate are not reduced. Casein, gelatin, arbutin, aesculin and starch are hydrolysed. Positive for the Voges-Proskauer reaction (API 20NE). Urease and $\beta$-galactosidase activities are absent. Assimilates D-glucose, L-arabinose, D-mannose, maltose, potassium gluconate, amygdalin, cellobiose, maltose, glycogen and $\beta$ gentiobiose. Acid is produced from lactose, D-glucose, cellobiose, starch, glycogen, amygdalin, arbutin, salicin, xylitol and gentiobiose. Assimilation or acid production is negative for the other carbon sources in the API $50 \mathrm{CH}$ and API 20NE strips. The type strain is resistant to discs containing sulfamethoxazole $(25 \mu \mathrm{g})$, vancomycin $(30 \mu \mathrm{g})$, meticillin $(5 \mu \mathrm{g})$, gentamicin $(10 \mu \mathrm{g})$, polymyxin $\mathrm{B}$ $(300 \mu \mathrm{g})$ and penicillin $\mathrm{G}(10 \mu \mathrm{g})$, but susceptible to erythromycin $(15 \mu \mathrm{g})$, ceftazidime $(30 \mu \mathrm{g})$, cephalothin $(30 \mu \mathrm{g})$, tetracycline $(30 \mu \mathrm{g})$, amoxicillin $(25 \mu \mathrm{g})$, cipro- floxacin $(5 \mu \mathrm{g})$, colistin sulfate $(50 \mu \mathrm{g})$, ticarcillin $(75 \mu \mathrm{g})$, sulfamethoxazole/trimethoprim $(1.25 / 23.75 \mu \mathrm{g})$, meropenem $(10 \mu \mathrm{g})$, streptomycin $(10 \mu \mathrm{g})$, lincomycin $(2 \mu \mathrm{g})$, rifampicin $(30 \mu \mathrm{g})$, cefoxitin $(30 \mu \mathrm{g})$, cephalothin $(30 \mu \mathrm{g})$, amoxicillin/clavulanic acid $(20 / 10 \mu \mathrm{g})$, chloramphenicol $(30 \mu \mathrm{g})$ and ampicillin $(10 \mu \mathrm{g})$. The major respiratory lipoquinone is MK-6. The major cellular fatty acids $(\geqslant 8 \%$ of the total) are iso- $\mathrm{C}_{15: 0}$, iso- $\mathrm{C}_{17: 0} 3-\mathrm{OH}$, iso- $\mathrm{C}_{17: 1} \omega 9 c$ and anteiso- $\mathrm{C}_{15: 0}$. Other cellular fatty acids are listed in Table 2. The $\mathrm{G}+\mathrm{C}$ content of the genomic DNA of the type strain is $34 \mathrm{~mol} \%$.

The type strain, ECP37 $7^{\mathrm{T}}\left(=\mathrm{LMG} 24684^{\mathrm{T}}=\mathrm{NBRC} 104927^{\mathrm{T}}\right.$ ), was isolated from a soil sample collected at a polluted site located in the industrial complex of Estarreja, northern Portugal.

\section{Acknowledgements}

C.P. and M. F. C. acknowledge research grants from Fundação para a Ciência e a Tecnologia (FCT), Portugal (SFRH/BD/25493/2005 and SFRH/BPD/44670/2008, respectively), and FCT projects POCI/AMB/ 60131/2004 and POCI/V.5/A0105/2005. We are indebted to Milton da Costa (University of Coimbra, Coimbra, Portugal) and to Fernanda Nobre for help with fatty acid analysis. We also thank the Unit of Research and Development of Nephrology (Faculty of Medicine, University of Porto, Porto, Portugal) for help with cell measurements.

\section{References}

Alexander, S. K. \& Strete, D. (2001). Microbiology: a Photographic Atlas for the Laboratory, 2nd edn. San Francisco: BenjaminCummings Publishing Company.

Benson, D. A., Karsch-Mizrachi, I., Lipman, D. J., Ostell, J. \& Wheeler, D. L. (2007). GenBank. Nucleic Acids Res 35, 21-25. 
Bernardet, J. F., Nakagawa, Y. \& Holmes, B. (2002). Proposed minimal standards for describing new taxa of the family Flavobacteriaceae and emended description of the family. Int J Syst Evol Microbiol 52, 1049-1070.

Bernardet, J.-F., Hugo, C. \& Bruun, B. (2006). The genera Chryseobacterium and Elizabethkingia. In The Prokaryotes: a Handbook on the Biology of Bacteria, 3rd edn, vol. 7, pp. 638-676. Edited by M. Dworkin, S. Falkow, E. Rosenberg, K. H. Schleifer \& E. Stackebrandt. New York: Springer.

Carvalho, M. F., Alves, C. C. T., Ferreira, M. I. M., De Marco, P. \& Castro, P. M. L. (2002). Isolation and initial characterization of a bacterial consortium able to mineralize fluorobenzene. Appl Environ Microbiol 68, 102-105.

Cashion, P., Holder-Franklin, M. A., McCully, J. \& Franklin, M. (1977). A rapid method for the base ratio determination of bacterial DNA. Anal Biochem 81, 461-466.

Comité de l'Antibiogramme de la Société Française de Microbiologie (1998). Communiqué du Comité de l'Antibiogramme de la Société Française de Microbiologie. Bull Soc Fr Microbiol 13, 243-258.

Costa, C. \& Jesus-Rydin, C. (2001). Site investigation on heavy metals contaminated ground in Estarreja - Portugal. Eng Geol 60, 39-47.

De Ley, J., Cattoir, H. \& Reynaerts, A. (1970). The quantitative measurement of DNA hybridization from renaturation rates. Eur $J$ Biochem 12, 133-142.

Felsenstein, J. (1995). PHYLIP (phylogeny inference package) version 3.57c. Distributed by the author. Department of Genome Sciences, University of Washington, Seattle, USA.

Gomori, G. (1990). Preparation of buffers. Methods Enzymol 1, 138146.

Hall, T. A. (1999). BioEdit: a user-friendly biological sequence alignment editor and analysis program for Windows 95/98/NT. Nucleic Acids Symp Ser 41, 95-98.

Hudson, J. A., Morgan, H. W. \& Daniel, R. M. (1986). A numerical classification of some Thermus isolates. J Gen Microbiol 132, 531-540.

Huß, V. A. R., Festl, H. \& Schleifer, K. H. (1983). Studies on the spectrophotometric determination of DNA hybridization from renaturation rates. Syst Appl Microbiol 4, 184-192.

Kämpfer, P., Lodders, N., Vaneechoutte, M. \& Wauters, G. (2009). Transfer of Sejongia antarctica, Sejongia jeonii, and Sejongia marina to the genus Chryseobacterium as Chryseobacterium antarcticum comb. nov., Chryseobacterium jeonii comb. nov. and Chryseobacterium marinum comb. nov. Int J Syst Evol Microbiol 59, 2238-2240.

Kim, M. K., Im, W.-T., Shin, Y. K., Lim, J. H., Kim, S.-H., Lee, B. C., Park, M.-Y., Lee, K. Y. \& Lee, S.-T. (2004). Kaistella koreensis gen. nov., sp. nov., a novel member of the Chryseobacterium-Bergeyella-Riemerella branch. Int J Syst Evol Microbiol 54, 2319-2324.
Kuykendall, L. D., Roy, M. A., O’Neill, J. J. \& Devine, T. E. (1988). Fatty acids, antibiotic resistance, and deoxyribonucleic acid homology groups of Bradyrhizobium japonicum. Int J Syst Bacteriol 38, 358-361.

Lane, D. J. (1991). 16S/23S sequencing. In Nucleic Acid Techniques in Bacterial Systematics, pp. 171-204. Edited by E. Stackebrandt \& M. Goodfellow. Chichester: Wiley.

Lee, K., Lee, H. K., Choi, T. H. \& Cho, J. C. (2007). Sejongia marina sp. nov., isolated from Antarctic seawater. Int J Syst Evol Microbiol 57, 2917-2921.

Mesbah, M., Premachandran, U. \& Whitman, W. B. (1989). Precise measurement of the $\mathrm{G}+\mathrm{C}$ content of deoxyribonucleic acid by highperformance liquid chromatography. Int J Syst Bacteriol 39, 159-167.

Murray, R. G. E., Doetsch, R. N. \& Robinow, F. (1994). Determinative and cytological light microscopy. In Methods for General and Molecular Bacteriology, pp. 21-41. Edited by P. Gerhardt, R. G. E. Murray, W. A. Wood \& N. R. Krieg. Washington, DC: American Society for Microbiology.

Oliveira, R. S., Dodd, J. C. \& Castro, P. M. L. (2001). The mycorrhizal status of Phragmites australis in several polluted soils and sediments of an industrialised region of Northern Portugal. Mycorrhiza 10, 241247.

Rainey, F. A., Ward-Rainey, N., Kroppenstedt, R. M. \& Stackebrandt, E. (1996). The genus Nocardiopsis represents a phylogenetically coherent taxon and a distinct actinomycete lineage: proposal of Nocardiopsaceae fam. nov. Int J Syst Bacteriol 46, 1088-1092.

Smibert, R. M. \& Krieg, N. R. (1994). Phenotypic characterization. In Methods for General and Molecular Bacteriology, pp. 611-651. Edited by P. Gerhardt, R. G. E. Murray, W. A. Wood \& N. R. Krieg. Washington, DC: American Society for Microbiology.

Tiago, I., Teixeira, I., Silva, S., Chung, P., Veríssimo, A. \& Manaia, C. (2004). Metabolic and genetic diversity of mesophilic and thermophilic bacteria isolated from composted municipal sludge on polyepsilon-caprolactones. Curr Microbiol 49, 407-414.

Tiago, I., Pires, C., Mendes, V., Morais, P. V., da Costa, M. \& Veríssimo, A. (2005). Microcella putealis gen. nov., sp. nov., a grampositive alkaliphilic bacterium isolated from a nonsaline alkaline groundwater. Syst Appl Microbiol 28, 479-487.

Tiago, I., Mendes, V., Pires, C., Morais, P. V., da Costa, M. \& Veríssimo, A. (2006). Chimaereicella alkaliphila gen. nov., sp. nov., a Gram-negative alkaliphilic bacterium isolated from a nonsaline alkaline groundwater. Syst Appl Microbiol 29, 100-108.

Vandamme, P., Bernardet, J.-F., Segers, P., Kersters, K. \& Holmes, B. (1994). New perspectives in the classification of the flavobacteria: description of Chryseobacterium gen. nov., Bergeyella gen. nov., and Empedobacter nom. rev. Int J Syst Bacteriol 44, 827-831.

Yi, H., Yoon, H. I. \& Chun, J. (2005). Sejongia antarctica gen. nov., sp. nov. and Sejongia jeonii sp. nov., isolated from the Antarctic. Int J Syst Evol Microbiol 55, 409-416. 